\title{
Traditional rice storage facilities and options for safe storage: A study in some selected flood-prone areas under Bhola district
}

\author{
M. K. Hasan ${ }^{1}$, M. Z. Abedin ${ }^{2}$, T. Islam ${ }^{3}$ and M. Z. Rahman ${ }^{2}$ \\ ${ }^{1}$ Engineering Section, Sylhet Agricultural University, Sylhet-3100, ${ }^{2}$ Department of Farm Structure and Environmental \\ Engineering, Bangladesh Agricultural University, Mymensingh-2202 and ${ }^{3}$ Department of Agricultural Construction and \\ Environmental Engineering, Sylhet Agricultural University, Sylhet-3100, Bangladesh \\ *E-mail: mzabedin95@yahoo.com
}

\begin{abstract}
The study aimed at identifying the existing rice storage facilities, problems and prospects at farmer's level in some selected five unions in two flood-prone upazillas under Bhola district of Bangladesh. The farmer's suggested policy options for safe storage of rice are also discussed. The selection of Upazilas and villages were done purposively whereas the sample households were selected randomly using stratified random sampling technique with arbitrary allocation. The farmers were classified as small, medium and large based their land ownership. Data on the average rice production, consumption, storage volume and costs of storage and losses of rice in different storage structures/containers from selected 50 farmers of study areas were collected through pre-tested questionnaire. The farmers generally used traditional storage structures such as Dole, Berh, Motka, Jala, Gola, Plastic drum and Gunny/Plastic bags for storing rice. Plastic drum, Gunny and Plastic bags and Motka/Jala were found more economical for the farmers considering the capital cost, expected life and storage loss. Over $90 \%$ of the farmers' felt the need for training on safe storage and over $80 \%$ of the small and medium farmers were interested in getting government help through loans, grants, etc. About $60 \%$ of the farmers expressed their interest on cooperative storage system to store and protect their food grains during the time of floods. Farmers opined to construct storage structures at an easily accessible place within their village or union under common or cooperative storage systems. The proposed storage system, on implementation, could be managed or overseen by a committee elected/selected by the cooperative society members.
\end{abstract}

Keywords: Rice storage facilities, Storage loss, Cooperative storage, Flood-prone area

\section{Introduction}

Rice is the staple food accounting for about 93 percent of the total food produced, about $70 \%$ of average calorie intake and $35 \%$ of household expenditure. Rice production is the largest contributor to farm income, while related trade and commerce are important sources of rural non-farm income (Ahmed, 2001). Bangladesh is the fourth largest rice producer in the world (FAO, 2010). In spite of this, the country is languishing with food deficit and each year the country has been importing over one million metric tons of rice at the expense of hard-earned foreign currency. A considerable amount of rice is lost in each stage of production especially in harvest, processing and storage. Previous studies showed that the losses of rice in post-harvest operations in Bangladesh were more than 13\% (Calverley, 1994; Quasem \& Siddiquee, 2009). In Bangladesh total area and production of rice is about 11.5 million hectares and over 35.0 million metric tons respectively (BBS, 2013). Bangladesh is the fourth largest rice producer in the world (FAO, 2010). The lands of Bangladesh are fixed but the volume of production is gradually increasing day by day due to the introduction of high yield variety rice, increasing cropping intensity, better cultural practices and modern post harvest technology. This increased production requires too much storage facilities. Most of the farmers of rural areas in Bangladesh store food grains in their house hold traditional storage structures like Dole, Berh, Gola, Kuthi, Gunny bag, Motka, Plastic/Steel drums, etc. These structures are not so durable and functional in providing optimum storage conditions. The grains stored in these structures are susceptible to damage by natural calamities like heavy rainfall, flood, cyclone and biotic and abiotic factors which cause a considerable damage and loss in every year. These storage losses of rice are playing a vital role in post-harvest losses (Abedin et al, 2009; Abedin \& Rahman, 2011). Therefore, it is of utmost important to improve the storage system for the rural areas, especially in the flood prone areas of Bangladesh. Storage systems for those particular flood prone areas are more significant and during the time of flood stored rice grains are damaged to a considerable extent. In Bangladesh cooperative or common storage facilities are almost absent. In order to reduce storage loss cooperative storage structures play important role in providing facilities for the farmers to store and protect their rice grains at the time of natural disaster. 
Seasonal changes in atmospheric temperature throughout the year also affect the grain storage system. The fluctuation of temperature causes storage of moisture due to condensation either at the top or bottom of the bin depending upon the direction of the natural convection of the air within the stored grains (Samajpati \& Sheikh, 1980). Spoilage may occur if counter measures are not taken. Moisture migration due to natural convection can be prevented by eliminating or drastically decreasing the temperature differential across a grain storage wall. Storage facilities in the flood prone or cyclone battered areas are also important to ensure food security among the affected areas. The farmers store food grains not only for their own consumption throughout the year but also to ensure secured supply of food for their families during the period of natural disaster. Due to traditional storage system, flood causes considerable losses to the stored food grain in the flood prone areas in our country. So, the storage system in private and government levels have to be improved for ensuring food security especially in the flood prone areas. Another economic importance of the proposed study is to reduce the losses of stored grains, select the low cost need based storage structure and better management of storing practices which would help both the qualitative and quantitative improvement of grain storage.

In our country large portion of population suffer chronic food insecurity due to poverty, natural disaster (like flood, cyclone, drought etc.), manmade calamities and disaster and unemployment of a group of people due to seasonality. The flood prone and cyclone prone areas draw special attention for ensuring food security when disaster affect in these areas so heavily and frequently. Flood and cyclone destroy the dwelling of farmers and damage grain storage structures of traditional nature along with food grains and make the people destitute and extreme poor. After disaster with rescue operation supply of food grain, especially in the flood prone areas are very important. A safe storage system of food grains plays a vital role for ensuring food security especially for the people who are fully dependent on cultivation.

Very limited study so far has been conducted in this flood prone area, particularly on loss evaluation of rice and the sustainable preventive measures for losses. Such a critical situation deserves a careful and effective investigation for addressing food security. The present study, therefore, will provide a framework to identify the problems and prospects of farmers. This study would also reveal a path of finding suitable locations for constructing storage structure and management of storage system so that the people in the flood prone areas would be able to store and protect their food grains based on their needs, emergency distribution, and price speculation.

Keeping eye on the above discussion, the objectives of the study were to (a) identify the existing rice storage facilities and problems in the selected flood prone areas, (b) evaluate the losses of rice in the storage structure at farmers' level, and (c) suggest policy options for safe storage system for the floodprone remote areas.

\section{Materials and Methods}

\section{Selection of the study area and farmers}

The study was conducted in Bhola sadar and Burhanuddin upazillas under Bhola district. The selected five unions were Char Shibpur, Uttar Dighaldi, Daksin Dighaldi, Kutba and Bara Manika under the study areas. The selection of Upazilas and villages were done purposively whereas the sample households were selected randomly using stratified random sampling technique with arbitrary allocation. The study areas were almost easily accessible for collecting data. Some community and private storage structures for rice was purposively visited. The farm households under rice cultivation were classified into three groups based on their land ownership and these were the small farmer having land up to 2.49 acres (0.40.99 hectares), medium farmer having land 2.50-7.49 acres (1.0-3.0 hectares) and large farmer having land with more than 7.50 acres (>3.0 hectares). 


\section{Collection and analysis of data}

Primary data were collected through farm survey with the help of pre-tested questionnaire. Data on average production, consumption, storage volume and storage costs and losses of rice in different storage structures from selected 50 farmers were collected through interviewing farmers involved in grain storage keeping in view the objectives of the study especially covering flood-prone areas. For collecting data personal visits were made to the house of sampled farmers. At the beginning of the interview, the aims and objectives of the study were explained to each farmer. Then the questions were asked in a very simple manner with explanation of questions where necessary and the replies were recorded in the questionnaire. The collected primary data was edited both at the field and at the laboratory. Data were also collected on policy options for safe storage through FGD. The secondary data was collected from publications of different research institutes including BRRI and Rice Foundation, BBS and websites. In achieving the objectives of the study the collected data were classified, tabulated and analyzed. Simple statistical techniques were followed in analyzing the data.

\section{Results and Discussion}

\section{Existing grain storage facilities in the study area}

Traditional storage structures/containers: The traditional and conventional storage structures used by the farmers in the study areas were Dole, Berh, Motka, Jala, Plastic drum, Gunny and Plastic bags and Gola. The rice stored in these structures/containers was susceptible to damage by natural disaster and attack of microorganisms, insects and rodents and caused considerable damage and loss. The photographic view of some the traditional storage structure is shown in Fig.1. The traditional storage structures had a number of limitations. The woven bamboo containers, like Dole, Berh, Dhari, etc had large top openings which caused serious losses by rodents and insects and also favoured the growth of microorganisms.

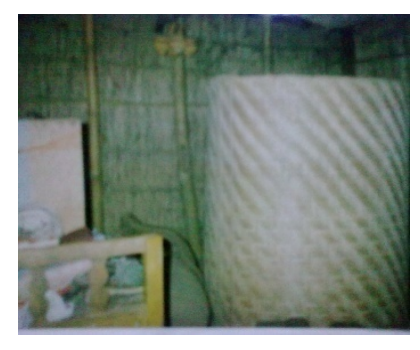

(a) Dole

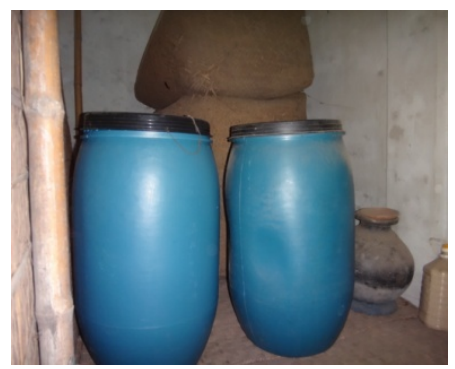

(e) Plastic drum

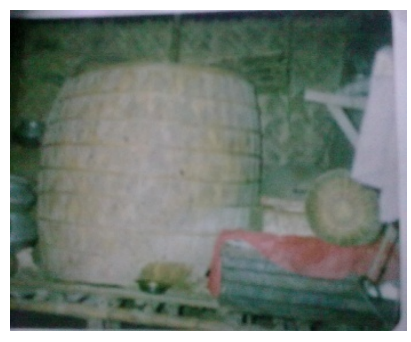

(b) Berh

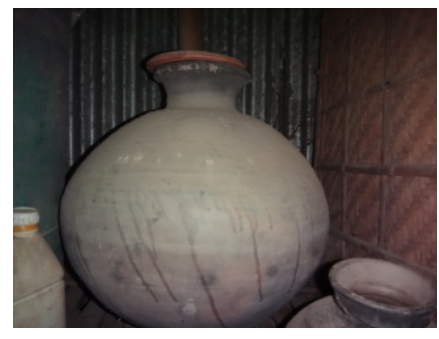

(c) Motka

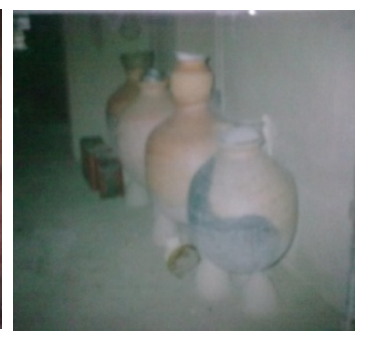

(d) Jala

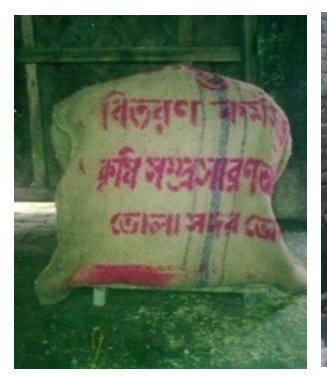

(f) Storage bag (DAE)

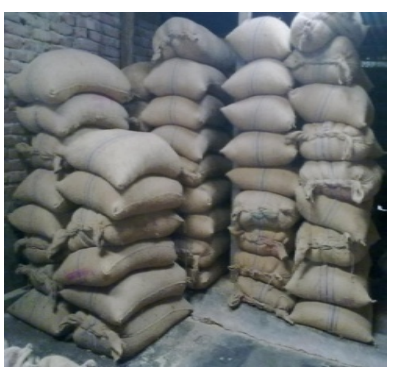

(g) Bag Storage

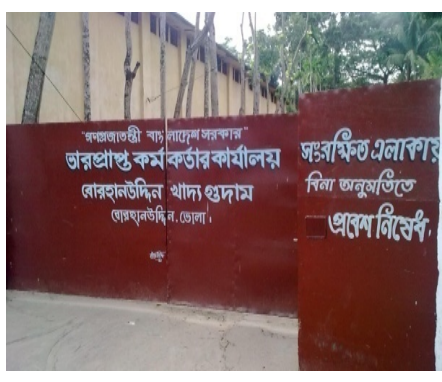

(h) LSD Food storage

Fig.1 Storage structures/containers used by the farmers 
Storage by government cooperatives and community: Government store food grains in grain silos i.e. Central Storage Depots (CSD) and Local Storage Depots (LSD). Storage quality is properly maintained in the government storage and hence the loss of storage retained within the acceptable margin. These public storage facilities are not enough to allow farmers for storing food grains. However, there was only one LSD godown in the study areas and there had no cooperative or common storage structure.

Net average production and storage of rice: The net average production, consumption and storage of rice by farm category are shown in Table 1 . Average net production and storage of rice increased with farm size and average consumption were almost same. Average storage for small, medium and large farms was $746.4,1492.8$ and $2985.6 \mathrm{~kg}$ of average acquisition respectively.

Table 1. Production, consumption and storage of rice by different farm sizes

\begin{tabular}{|c|c|c|c|}
\hline Farm category & $\begin{array}{c}\text { Average net } \\
\text { production }(\mathrm{kg})\end{array}$ & $\begin{array}{c}\text { Average consumption } \\
\text { for family }(\mathrm{kg})\end{array}$ & $\begin{array}{c}\text { Average } \\
\text { storage }(\mathrm{kg})\end{array}$ \\
\hline Small & 5941.2 & 2425.8 & 746.4 \\
\hline Medium & 9553.9 & 2612.4 & 1492.8 \\
\hline Large & 42470.2 & 2799.0 & 2985.6 \\
\hline
\end{tabular}

\section{Grain storage structure used by the farmers}

Farmers of the study areas used traditional grain storage structure like Dole, Motka, Jala, Plastic drum, Gunny bag, Berh and Gola etc. The description of traditional rice storage structure of sampled farmers at Bhola sadar and Burhanuddin upazilas is given in Table 2. Table 2 also reveals that Dole, MotkalJala, Plastic drum, Gunny bag, Berh and Gola used by the farmers were 42, 67, 50, 50, 67, 59 percent for small farm; 43, 54, 29, 39, 43 and 65 percent respectively for medium farms; 40, 70, 40, 30, 50 and 60 percent respectively for large farms.

Table 2. Traditional rice storage structures used by the sampled farm in the study areas

\begin{tabular}{|l|l|c|c|c|c|c|c|}
\hline \multirow{2}{*}{$\begin{array}{l}\text { Farm } \\
\text { category }\end{array}$} & \multirow{2}{*}{ No. of farm } & \multicolumn{5}{|c|}{ No. of farms used the traditional storage structures/containers } \\
\cline { 3 - 8 } & & Dole & Motka/Jala & Plastic drum & Gunny bag & Berh & Gola \\
\hline Small & 12 & $5(42)$ & $8(67)$ & $6(50)$ & $6(50)$ & $8(67)$ & $7(59)$ \\
\hline Medium & 28 & $12(43)$ & $15(54)$ & $8(29)$ & $11(39)$ & $12(43)$ & $18(65)$ \\
\hline Large & 10 & $4(40)$ & $7(70)$ & $4(40)$ & $3(30)$ & $5(50)$ & $6(60)$ \\
\hline
\end{tabular}

Figures in the parentheses indicate percentage of farms usages traditional storage structures/containers

\section{Storage cost and loss of rice in different storage structure}

The study areas were flood prone and remote and, therefore, the storage systems practiced were mostly conventional and traditional. Storage cost and storage loss vary in different storage structures depending upon the types of grains stored, maintenance of storage quality, duration, etc. Table 3 reveals that for duration of storage was 5-6 months in study area, and the cost of rice storage in Dole is Tk.5 per $40 \mathrm{~kg}$ which is the minimum but the storage loss was $4.2 \%$ that was the maximum. The storage cost in Plastic drum is Tk.16 per $40 \mathrm{~kg}$ but the loss was the minimum (1.0\%). Considering the capital cost, expected life, storage loss Plastic drum, gunny bag, Motka/Jala were more economical for the farmers.

Table 3. Storage cost and loss of rice in different storage structures

\begin{tabular}{|c|c|c|c|c|c|}
\hline $\begin{array}{c}\text { Storage } \\
\text { structures }\end{array}$ & $\begin{array}{c}\text { Average } \\
\text { capacity }(\mathrm{kg})\end{array}$ & $\begin{array}{c}\text { Capital cost } \\
(\mathrm{Tk})\end{array}$ & $\begin{array}{c}\text { Expected life } \\
(\text { year})\end{array}$ & $\begin{array}{c}\text { Cost per 40 kg } \\
(\mathrm{Tk})\end{array}$ & $\begin{array}{c}\text { Storage losses } \\
(\%)\end{array}$ \\
\hline Dole & 1100 & 700 & 5 & 5.0 & 4.20 \\
\hline Motka/Jala & 150 & 500 & 10 & 13.5 & 1.25 \\
\hline Plastic drum & 150 & 600 & 10 & 16.0 & 1.00 \\
\hline Gunny bag & 75 & 50 & 3 & 9.0 & 1.25 \\
\hline Berh & 1500 & 1000 & 5 & 5.5 & 3.00 \\
\hline Gola & 4500 & 3000 & 10 & 2.5 & 2.50 \\
\hline
\end{tabular}




\section{Storage cost, loss and germination rate of seed storage by different farms}

Farmers stored rice, wheat and mustard, etc as seed for the next sowing season. They took special care from harvesting to storage for seed preparation. So, the cost is comparatively high but loss is low. Table 4 shows the storage cost, loss and germination rate of different food grains in different structures for an average period of 8-9 months in the study area by farm category.

Table 4. Storage cost, loss and germination rate of seed storage by farm category

\begin{tabular}{|c|c|c|c|c|}
\hline $\begin{array}{c}\text { Farm } \\
\text { category }\end{array}$ & $\begin{array}{c}\text { Storage } \\
\text { structure }\end{array}$ & $\begin{array}{c}\text { Cost of storage per 40 } \\
\mathrm{kg}(\mathrm{Tk} .)\end{array}$ & Storage losses (\%) & $\begin{array}{c}\text { Germination } \\
\text { rate (\%) }\end{array}$ \\
\hline Small & Motka/ Jhala & 13.5 & 1.25 & 82 \\
\hline Medium & Plastic drum & 16 & 1.00 & 85 \\
\hline Large & Gunny bag & 9 & 1.25 & 80 \\
\hline
\end{tabular}

\section{Flood affecting farms and storage of food grains}

Bhola sadar and Burhanuddin upazillas are basically flood-prone area. Among the five unions, the scenarios of three unions are worse. A large portion of the people in these unions has been suffering every year from the impending danger of flood damage. Table 5 shows the number of affected farm and damage of stored rice.

Table 5. Farms affected by flood and damaged of stored grain

\begin{tabular}{|c|c|c|c|c|}
\hline $\begin{array}{c}\text { Farm } \\
\text { Category }\end{array}$ & $\begin{array}{c}\text { Number of } \\
\text { farm }\end{array}$ & $\begin{array}{c}\text { Number of farm affected } \\
\text { by flood }\end{array}$ & $\begin{array}{c}\text { \% of farms affected } \\
\text { by flood }\end{array}$ & $\begin{array}{c}\text { Damage of } \\
\text { stored rice (\%) }\end{array}$ \\
\hline Small & 12 & 10 & 84 & 14 \\
\hline Medium & 28 & 22 & 79 & 12 \\
\hline Large & 10 & 5 & 50 & 11 \\
\hline
\end{tabular}

\section{Common and cooperative storage}

The flood causes considerable damages in most of the farm almost in every year. There was no common or cooperative storage structure in the study areas. But the respondent of the sampled farms and traders expressed their interest in common or cooperative storage. Table 6 shows the farm category-wise appreciation of farmers in common and cooperative storage systems.

Table 6. Appreciation of common and cooperative storage in terms of farm category

\begin{tabular}{|l|c|c|c|c|c|}
\hline $\begin{array}{c}\text { Farm } \\
\text { category }\end{array}$ & $\begin{array}{c}\text { Number } \\
\text { of farmer }\end{array}$ & $\begin{array}{c}\text { Interested in commercial } \\
\text { storage structure }\end{array}$ & $\begin{array}{c}\% \text { of } \\
\text { farmer }\end{array}$ & $\begin{array}{c}\text { Interested for } \\
\text { cooperative storage }\end{array}$ & $\begin{array}{c}\% \text { of } \\
\text { Farmer }\end{array}$ \\
\hline Small & 14 & 4 & 33 & 8 & 67 \\
\hline Medium & 28 & 12 & 43 & 16 & 57 \\
\hline Large & 10 & 4 & 40 & 6 & 60 \\
\hline
\end{tabular}

\section{Training on safe storage and government assistance}

The farmers have short of knowledge about the importance of storage and its management systems and this is the common scenario in Bangladesh. The financial conditions of the farmers are not good. They need government assistance in various forms for the production and storage of produced crops especially food grain. This type of help is especially needed for the flood-prone areas of the country as a whole. During the survey works, the farmers' opined the need for storage related training through method demonstration and technology fairs and government help in terms of loan, grants, etc. Table 7 shows the farmers' interest in training on safe storage and government help through loans and grants, etc. 
Table 7. Training on storage and government assistance for different farm category

\begin{tabular}{|l|c|c|c|c|c|}
\hline $\begin{array}{c}\text { Farm } \\
\text { category }\end{array}$ & $\begin{array}{c}\text { No. of } \\
\text { farmer }\end{array}$ & $\begin{array}{c}\text { No. of farmer } \\
\text { interested for } \\
\text { training }\end{array}$ & $\begin{array}{c}\text { Interested } \\
\text { farmers for } \\
\text { training (\%) }\end{array}$ & $\begin{array}{c}\text { No. of farmers interested } \\
\text { in getting government help } \\
\text { (loans, grants, etc) }\end{array}$ & $\begin{array}{c}\text { Interested } \\
\text { farmers for } \\
\text { getting help (\%) }\end{array}$ \\
\hline Small & 12 & 11 & 92 & 10 & 84 \\
\hline Medium & 28 & 27 & 96 & 25 & 89 \\
\hline Large & 10 & 10 & 100 & 7 & 70 \\
\hline
\end{tabular}

\section{Need based storage system}

In the study area, on an average $71 \%$ farms were affected by flood and average $12 \%$ stored grains were damaged in the flood of 2009. For ensuring security and storage quality the structure should have the storage capacity of minimum 60 metric tons so that 150 farmers could store per head $400 \mathrm{~kg}$ food grains before disaster and the well planned structure could be erected on a land of about 5 decimals.

\section{Conclusions and policy recommendation}

The farmers stored their rice in indoor type traditional storage structures like Dole, Berh, Plastic drum. Motka, Jala, Gunny, Plastic bag and Gola. Tendency of using Motka, Berh and Gola are higher which are not so durable and storage losses due to various factors are high. During flood the houses and storage structures and stored grains of farm are damaged partially or fully. For these reason, there is no alternative other than cooperative storage structure constructed at safe and elevated place. Farmers of the study areas have short of knowledge on storage and they need government help like loan, training etc. The farmers are languishing with the impending danger of flood almost in every year, they suggested for safely constructed cooperative storage structure at easily accessible and safe place for ensuring security and storage quality. Some of the policies suggested for safe storage are as follows:

(a) Plinth level of the house of farmers in flood-prone areas could be raised above flood level to protect the traditional/conventional storage system at farmers' level. Government storage system should be extended in the union and Hat/Bazar level.

(b) Government should provide assistance (loan, training, etc) for the development of safe storage system at farmers' level. Every Union Parishad of Bangladesh has one small VGD godown, The CSD or LSD godowns could be increased that would help storage of relief food grains at the time of disaster. In the flood/cyclone prone areas the number of flood-cum-cyclone shelter including cooperative storage system for food grain should be increased.

(c) Farmers' awareness and training program on safe storage of rice should be implemented. The GOs and NGOs could be initiated to take the lead involving the private sector development partners.

\section{References}

Abedin, M.Z, Rahman, M.Z., Rahman, M.M. 2009. Traditional rice storage structures and in-store losses: An assessment on selected upazilas under Rangpur district. Bangladesh Journal of Agricultural Engineering. 20 (1\&2): 11-23.

Abedin, M.Z., Rahman, M.Z. 2011. Losses and quality of stored rice at farmers' level: An assessment in selected regions of Bangladesh. Bangladesh Journal of Agricultural Engineering. 22 (1\&2): 19-35.

Ahmed, R. 2001. Retrospect and prospects of the rice economy of Bangladesh. The University Press Limited, Dhaka.

BBS. 2013. Statistical Yearbook of Bangladesh 2008. Ministry of Planning. Government of the Peoples' Republic of Bangladesh. Dhaka.

Calverley, D.J.B. 1994. Programme for the prevention of food losses: A study of eleven projects in Asia concerned with rice. Final report, FAO.

FAO. 2010. Food Outlook: Global Market Analysis, Global Information and Early Warning System, An internet version. www.fao.org/docrep/012/ak349e/ak349e00.pdf.

Quasem, M.A. and Siddiquee, M.A. 2009. 'Reduction of Post-harvest losses in Rice', Paper presented at CIRDAP Workshop, on Nov. 23, 2009, CIRDAP, Dhaka.

Samajpati, J.N. and Sheikh, M.S.A. 1980. Paddy and rice storage in Bangladesh with emphasis on insect infestation. Agricultural Mechanization in Asia. 11(1): 69-72. 